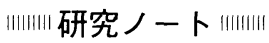

\title{
下宿学生の自炊の仕方と食事内容
}

馬 路 泰 蔵

岐皁大学教育学部

\section{Dietary Habit of Students Cooking Their Own Meals and the Quality of Meals}

\author{
Taizo Maji \\ Faculty of Education, Gifu University
}

A survey was performed on 13 male and 13 female students living in lodgings concerning their dietary life for 3 weeks.

1) Male students cooked for themselves less frequently than female students, and skipped meals or ate outside more often. The difference in skipped meals was primarily due to the fact if they had breakfast or not. The students who prepared $2 / 3$ of all their meals on their own rarely skipped meals. These results suggest that ability or desire to cook on their own is necessary to prevent the students from skipping meals.

2) If students wanted to cook their meals more often, they needed to improve their culinary skills and use more variety of foods.

3) Frequency of cooking their own meals was highly correlated with the number of foods they ate per meal, but was only slightly correlated with the better balance of food combinations.

4) The students who rarely cooked for themselves tended to rely on commercially prepared foods or simple dishes such as stir-fried dishes.

5) Frequency of preparing meals on their own was highly correlated with the number of kitchen utensils and the variety of seasonings.

6) Those students who cooked their meals less often and skipped meals or ate out more often had more variety of utensils for drinks such as tea and coffee, indicating their willingness to satisfy themselves by drinks.

Jpn. J. Nutr., 46 ( 3 ) 129 138 (1988)

\section{緒言}

青年層の食生活を他世代と比較すると，欠食が多く11，脂質エネルギー比が高い2)など，栄養的に問題のあ る者が多いことが知られている。このような青年層の中でも，男性の単身者の食生活に最も問題が起きやす

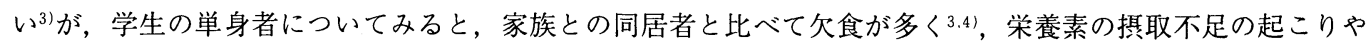
すい3.5)ことが報告されている。このように，単身者の食生活の問題は 1 日の食事全体について，家族との同 居者と対比して，論じられることが多い。

ところで，下宿生など学生の単身者は，自炊による食事作りをする者も少なくない。自炊による食事作りは， 外食に比べて食に関する意識や知識・能力をより明瞭に反映しやすいと考えられる。そこで, 本報告は自炊に よる食事作りに関する問題に焦点を絞って検討した。

針谷 ${ }^{6)}$ は, 下宿女子学生において, 高校までの調理経験の多い者ほど自炊による食事に問題が少ないことを

Key words : student-lodgers, manner of taking meals, manner of cooking meals, culinary skills 下宿学生, 食事方法, 自炊方法, 調理能力 
報告した。この結果は，食事作りには調理経験が必要なことを示している。自炊を行う学生の中には男性が少 なくないが，日本においては食事作りは女性の仕事とする役割意識が強く，男性は食に関する経験や教育の機 会が女性より少ない。その結果，学生においても男性は食に関する知識・関心4.7)や調理の能力8)が女性より劣 っており，高校までの調理経験も少ないこと年が報告されている。したがって，女性だけでなく男性を含めて 自炊による食事作りを検討することによって, 食に関する知識や能力, とりわけ調理の能力の不足と食事作り に扔ける問題点との関連をより明確にすることが期待できる。

本報告では，下宿学生の食生活，特に自炊の仕方と，対象者の食に関する能力や条件との関係を把握しょう と試みた。まず, 25 種の料理 ${ }^{8}$ の調理可能数, または繁用される食品を用いて作る料理の種類数が, 調理能力 を反映する指標と考え，それらと自炊頻度や食品の使用状況などの自炊内容との関連を検討することとした。 また，自炊を多く行う者は，外食に頼りがちな者より調理器具の所有・使用が多いことが報告されている うに, 単身者の食事作りは調理場所・器具の条件によって影響されるはずである。本調査では, 調理機器およ び調味料などの所有数, ならびに調理場所の状況と, 食事作りとの関係をも検討することによって, 単身学生 の食事作りに影響する因子をより多面的にとらえょうとした。

\section{調查および集計方法}

\section{1. 調査対象者}

岐阜大学に在学する学生で, 自炊をしている下宿学生の男女各13人を調査対象とした。対象者の学部, 学年 を，表 1 に示した。

\section{2. 調查の方法および時期}

1 週間の食事について，1979年 4,6 月および11月の 3 回，対象者に記録させた。食事記録には，朝・昼・ 夕および夜食について, 自炊・外食の別, 料理名, およびその材料を記載させた。記録の不明瞭な点について は, 回収時の聞き取りによって確認を行った。

1979年10月に対象者の下宿を訪問し, 調理機器・食品の所有状況, 台所を含む下宿の間取りの実態調査, な らびに25種の料理8)の調理可否についての聞き取り調査を行った。さらに, 繁用される調味料, 副材料㧍よび 調理機器の所有は，調査票によって確認した。なお，調理可否を問うた料理は，ゆで卵，卵焼き，大根おろし， 野菜サラダ, サンドイッチ, 野菜炒め, チャーハン, カレーライス, 味噌汁, さつまいもの天ぷら, シチュー, さけの塩焼き, ほうれん草の油炒め, うどん, 鷄肉の唐揚げ, ほうれん草のお浸し, 粉ふきいも, かき卵汁, きゅうりの酢の物, ハンバーグ, コロッケ, 茶碗蒸し, ねぎといかの味噌和え, かぼちゃの煮物, および鷄肉 の酒蒸しである。

\section{3. 集計方法}

朝・昼・夕食のみを集計の対象とし, 夜 食・間食は集計の対象から除いた。対象食事 をまず自炊・外食・笛食に分類した。自炊と は，その食事のために何らかの調理行為がな された食事とした。したがって，購入した食 品のみを下宿でそのまま食べた場合は外食と し，そのような時でも同時にコーヒー・紅茶

表 1 調査対象者の内訳 (人)

\begin{tabular}{cccccc}
\hline 学 部 & 男性 & 女性 & 学年 & 男性 & 女性 \\
\hline 教 育 学 部 & 0 & 12 & 2 年 & 1 & 4 \\
農 学 部 & 2 & 1 & 3 年 & 4 & 0 \\
工 学 部 & 8 & 0 & 4 年 & 6 & 9 \\
医 学 部 & 3 & 0 & 5 年 & 1 & 0 \\
& & & 6 年 & 1 & 0 \\
\hline
\end{tabular}


などを入れて飲んだ場合は自炊とした。また,コーヒー・紅茶などの飲料のみを契食した時は，欠食とした。 昼食については，下宿で食事をした場合だけでなく，自分で作った料理を含む弁当を大学などで食べた場合も 自炊として集計した。

食品の使用状況および “副食” の料理に関する集計は，自炊による食事を対象に行った。副食の料理は，足 立ら ${ }^{10)}$ の定義による主食以外の料理とした。さらに, 親子どんぶり, カレーライス, サンドイッチのようなど んぶり・皿物は, その中の穀類の料理（食品）以外の部分を独立の料理とみなし, これらの料理と前述の副食 の料理と合わせて “副食”の料理とした。また, 牛乳の生飲は副食に含め, コーヒー・紅茶などの嗜好飲料は 副食の料理に含めなかった。

“副食”の料理は，自分で作った物・非調理・残り物の 3 種に区分した。非調理の料理は，そうざい食品の 他に, 温めるだけのレトルト食品, 湯を注ぐだけのカップスープ (レトルト食品と同じとみなした), および 果物の生食とし，これらの物は繰り返し出現しても非調理の料理とした。さらに，自分で作った料理について は, 山崎ら ${ }^{11)}$ の分類に準じて，調理方法による分類を行った。

料理中の食材料・調味料・香辛料を日本食品標準成分表に準じて分類し, 食品群ごとの 1 食当たりの出現率 を算出した。さらに, 香川式 4 つの基礎食品群のうち, 第 1 または $2 ， 3 ， 4$ 群のいずれの群からも 1 食品以 上使用している食事を, 食品組み合わせ“良好”として, これらの食事の出現率を算出した。

調理器具は, 炊飯器・トースター・ガスコンロ・冷蔵庫などそのものが発熱 (冷却) する熱源機器, なべ・ フライパンなどの加熱器具, 包丁・皮むきのように主に切る操作に用いられる下ごしらえ器具, 計量カップ・ 科などの計量器具, ポット・オイルポットなどの保存器具, きゅうす・コーヒーサイうォンなどの嗜好飲料器 具，およびその他の器具に分けて所有状況を集計した。その他の器具には，すりばち・泡立て・フライ返しの ように，混合・変形を主な目的とした器具だけでなく，しゃもじ・玉じゃくしなどの盛り付け用の器具や，ざ る・ボールなども含まれるが, 後者も混合・変形に使 用されることがあるので, 混合・変形器具と呼称する こととした。なお，なべ・フライパン・ボールは, 大 きさの異なるものであっても, 形・使用目的が異なら なければ, 1 種類として集計した。

\section{結果および考察}

\section{1. 各調査について}

(1) 自炊 · 外食 $\cdot$ 欠食回数

3 週間の総食事 63 食に関する食事状況を表 2 に示し た。男性は女性より自炊回数が少なく，外食および欠 食回数が多かったが,この結果は他の調査 ${ }^{3.4)}$ と同様 のものである。食事ごとにみると, 欠食はそのほとん どが朝食に現れ, 自炊および欠食回数の男女差は, 主 として朝食における差によるものであった。

聞き取り調査の結果, 午前 8 時前に起床する対象者 は, 男性 1 人, 女性 11 人であった。また, 起床後下宿

表 2 自炊, 外食および欠食の回数*1

\begin{tabular}{ccccc}
\hline & & & 男 性 & 女 性 \\
\hline & 朝 & 食 & $6.5 \pm 1.0$ & $16.3 \pm 1.0^{* * *}$ \\
自 & 昼 & 食 & $3.6 \pm 1.1$ & $8.4 \pm 1.2^{* *}$ \\
炊 & 夕 & 食 & $11.8 \pm 1.2$ & $13.5 \pm 0.8$ \\
\cline { 2 - 5 } & 計 & $22.0 \pm 2.1$ & $38.2 \pm 2.2^{* * *}$ \\
\hline & 朝 & 食 & $5.6 \pm 1.0$ & $2.6 \pm 0.6^{*}$ \\
外 & 昼 & 食 & $16.7 \pm 1.2$ & $12.2 \pm 1.1^{*}$ \\
食 & 夕 & 食 & $8.9 \pm 1.3$ & $7.4 \pm 0.8$ \\
\cline { 2 - 5 } & 計 & $31.2 \pm 2.8$ & $22.3 \pm 1.3^{* *}$ \\
\hline & 朝 & 食 & $8.8 \pm 1.2$ & $2.1 \pm 0.9^{* * *}$ \\
欠 & 昼 & 食 & $0.7 \pm 0.3$ & $0.4 \pm 0.2$ \\
食 & 夕 & 食 & $0.3 \pm 0.2$ & $0.1 \pm 0.1$ \\
\cline { 2 - 4 } & 計 & $9.9 \pm 1.4$ & $2.5 \pm 1.0^{* * *}$ \\
\hline
\end{tabular}

注） *1 3 週間の食事についての回数を, 平 均土標準䛊差として表した。

男女差 : *** $p<0.001,{ }^{* *} \quad p<0.01$, $* \quad p<0.05$ 

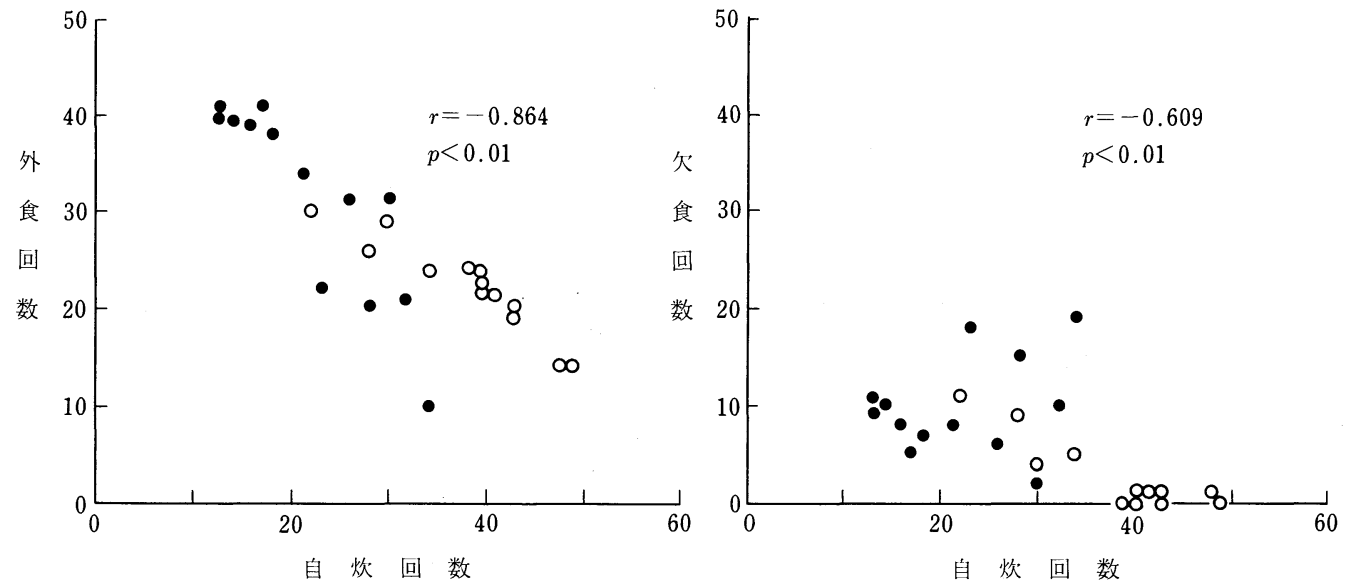

○男性, ○女性

図 1 外食および欠食回数と自炊回数の関係

を離れるまでの時間が 1 時間以上の者は，男性 2 人， 女性11人であった。したがって，男性において朝食の 自炊が少ないのは, 起床時刻が遅く, 起きてから下宿 を離れるまでの時間が少ないことによるものといえる。 夕食は欠食がほとんどなく，自炊，外食，欠食とも その回数に有意の男女差が認められなかった。聞き取 り調査において，外食は，サークル活動またはアルバ イトのある日に行われやすいことが示唆され，大学に おける授業などの終了時刻との関係は示されなかった。 大学生協の大学生の食生活調査 ${ }^{4}$ によると, 夕食にお ける単身学生の外食は, 男性のほうが女性より多いこ とが示され，本調査の結果と異なっている。この相違 は, 本調査が自炊している単身学生のみを対象とし,
表 3 “副食”料理の調理区分別料理数および 使用食品数 （ 1 食当たり）

男 性 女 性

\begin{tabular}{cll}
\hline 料理 数*1 & & \\
自 作 & $1.04 \pm 0.14$ & $1.84 \pm 0.08^{* * *}$ \\
非調 理 & $0.56 \pm 0.12$ & $0.64 \pm 0.07$ \\
残 り 物 & $0.16 \pm 0.05$ & $0.26 \pm 0.06$ \\
\hline 計 & $1.76 \pm 0.16$ & $2.74 \pm 0.12^{* * *}$ \\
\hline 食品数*1 & $4.02 \pm 0.14$ & $5.58 \pm 0.10^{* * *}$ \\
\hline
\end{tabular}

注）*1 料理数については対象者（男女とも 各13人）に対する，また食品数につ いては食事回数（男性 285食, 女性 497食）に対する平均土標準誤差とし て表した。

男女差 : *** $p<0.001$

外食に依存した学生を除いているためと思われる。昼食の自炊は女性のほうが男性より多かったが，これは女 性の中に弁当を作った者がいることによるものである。

自炊回数と外食または欠食回数との関係を図 1 に示した。外食回数は自炊回数と逆相関を示した。欠食回数 も全体としては自炊回数と逆相関したが，むしろ自炊回数39食を境界として欠食がほとんどない対象者と欠食 が多い対象者の 2 つグループに分けたほうがよいかもしれない。39食は総食事の約 $2 / 3$ に相当し, 朝食およ び夕食の大部分が自炊されていることを表している。また，飡はそのほとんどが朝食に現れることから，朝 食の欠食の解消には自炊が必要なことを示している。

(2) 副食料理

副食料理の調理区分，および 1 食当たりの食品の使用数を表 3 に示した。 1 食当たりの副食料理数は女性の ほうが有意に多かったが，これは主に自分で作った料理数が多いことによるものであった。また，1 食当たり の食品数も女性が有意に多く使用していた。 
（3）自分で作った料理 自分で作った料理につ いて, 調理方法別の 1 食 当たりの出現率および調 理者数を表 4 に示した。 男女ともほとんどの対象 者が調理し, 出現率が 10\%を越える料理は, 汁 物, なま物, 焼き物, 炒 め物および煮物であった。 また，女性が男性より有 意に出現率の高かった料 理は, なま物, 蒸し物, 茹で物および和え物・浸 し物・酢の物であった。

特に和え物・浸し物・酢の物については，女性の出現率が高いだけでなく，その調理者数も有意に多かった。

表 5 主材料の食品群別食品種類数および出現率

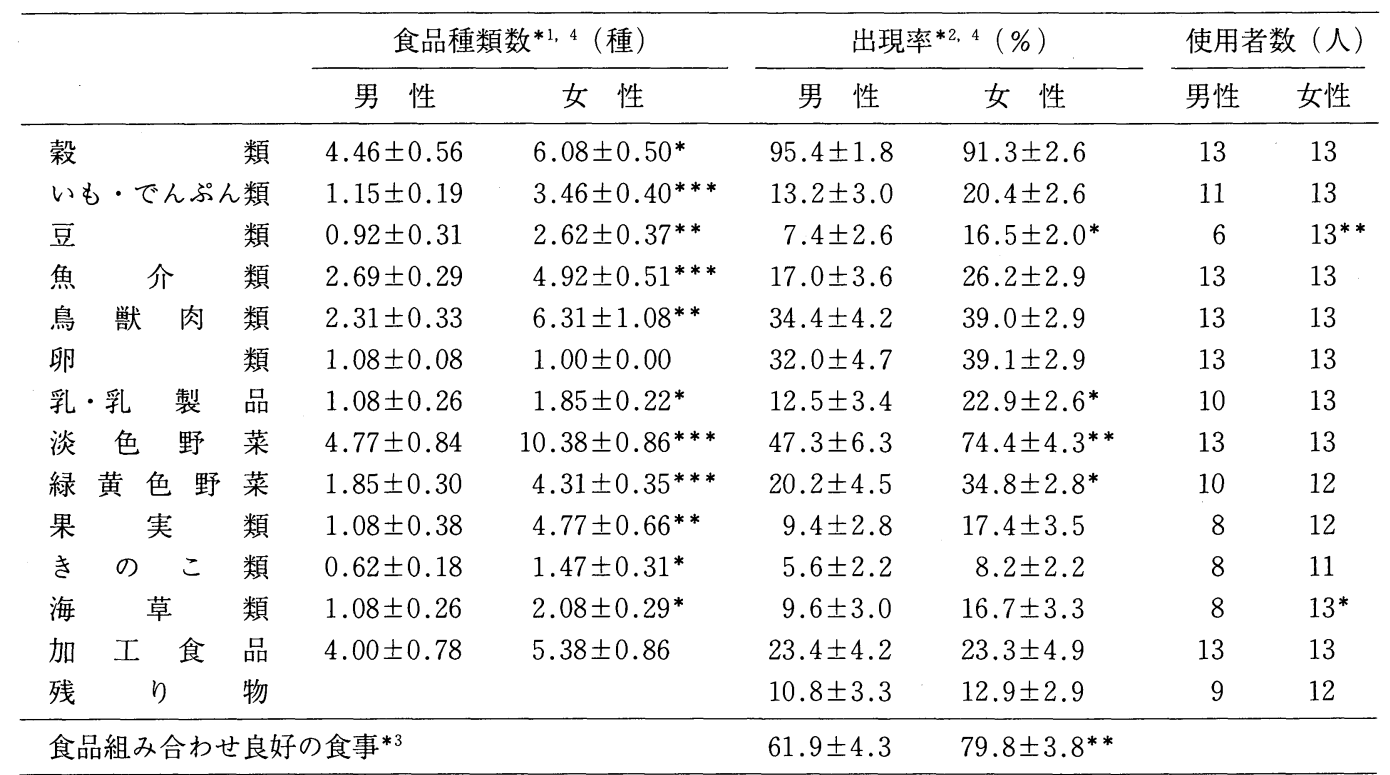

注） $* 1$ 全調査期間中に使用された食品の種類数。

*2 自炊回数に対する主材料として使用された食事の回数の比率（％）をその食品群の出現食事率と した。

*3 香川式 4 つの基礎食品群のうち， 1 または $2 ， 3 ， 4$ 群のいずれの群からも 1 食品以上使用して いる食事。

*4 食品種類数および出現率は，平均土標準誤差として表した。

男女差： ${ }^{* *} p<0.001,{ }^{* *} p<0.01,{ }^{*} p<0.05$ (使用者数は $\chi^{2}$ 検定，その他は $t$ 検定) 
表 6 繁用食品に対する展開料理数と調理能力

\begin{tabular}{|c|c|c|c|c|c|}
\hline & & \multicolumn{2}{|c|}{ 料理数 (種) } & \multicolumn{2}{|c|}{ 調理者数*4（人） } \\
\hline & & 男 性 & 女 性 & 男性 & 女性 \\
\hline \multicolumn{6}{|c|}{ 食品別展開料理数*1, 5} \\
\hline じ & やがいも & $1.69 \pm 0.35$ & $2.69 \pm 0.33^{*}$ & 13 & 13 \\
\hline 卵 & & $4.54 \pm 0.86$ & $9.46 \pm 1.02 * *$ & 13 & 13 \\
\hline 肉 & & $3.38 \pm 0.59$ & $6.31 \pm 1.06^{*}$ & 13 & 12 \\
\hline 牛 & 乳 ${ }^{* 2}$ & $0.92 \pm 0.24$ & $1.92 \pm 0.33^{*}$ & 8 & 12 \\
\hline ピ & - マン & $1.31 \pm 0.46$ & $2.15 \pm 0.25$ & 8 & 12 \\
\hline キ & ヤ ベ ツ & $2.46 \pm 0.39$ & $3.69 \pm 0.47$ & 11 & 12 \\
\hline 玉 & ね ぎ & $3.85 \pm 0.64$ & $6.23 \pm 0.93^{*}$ & 13 & 13 \\
\hline に & んじん & $1.62 \pm 0.62$ & $5.15 \pm 0.86^{* *}$ & 9 & 12 \\
\hline \multicolumn{2}{|c|}{ 調理能力*3, 5} & $14.46 \pm 0.87$ & $22.85 \pm 0.65^{* * *}$ & & \\
\hline
\end{tabular}

注） ${ }^{* 1}$ 各食材を用いて実際に調理された料理の種類数。

$* 2$ 牛乳の生飲も料理として集計した。

*3 25 種の料理について調理可能な料理数（アンケートによる）。

*4 各食品を料理に使用した人数。

*5 展開料理数および調理能力の料理数は平均土標準誤差として表した。

男女差: ${ }^{* * *} p<0.001,{ }^{* *} p<0.01,{ }^{*} p<0.05$

また，女性に作られたなま物の多くは野菜サラダであった。

(4) 主材料

各食品群について，1 食当たり使用食品の種類数と出現率を表 5 に示した。食品の種類数は, 卵類と加工食 品を除く食品群で男性が女性より有意に少なく, 食品群ごとの出現率も豆類, 乳・乳製品, 淡色野菜拧よび緑 黄色野菜について男性が女性より有意に低かった。特に豆類については，使用者数についても男性が女性より 有意に少なかった。前述のように，なま物（サラダ）および和え物・浸し物・酢の物のような野菜を用いた料 理の少ないことが，男性における野菜類の出現率が低い理由の 1 つとして考えられる。

食品組み合わせが “良好” な食事の出現率を表 5 の最下段に示したが，この出現率も男性のほうが女性より 有意に低かった。男性は 1 食当たりの主材料食品数が少なく, 野菜類の使用が少なかったため, 食品の組み合 わせを良好に保っことが困難であったと思われる。

(5) 展開料理数と調理能力

男女とも 8 人以上が使用している 8 種の食品について，それらを用いて作られた料理の種類数（展開料理 数）を表 6 に示した。じゃがいも，卵，肉，牛乳，玉ねぎ，にんじんを用いた料理は，女性が男性より多く作 っていた。また，聞き取り調查で提示した 25 種の料理について，その調理可能数（調理能力）を表 6 の最下段 に示したが，女性は男性より調理可能な料理数が有意に多かった。

表 5 に示したように，男性はほとんどの食品群で女性より自炊に用いた食品の種類が少なかったが，その理 由として, 自炊回数が少ないことがまず考えられる。また, 展開料理数の少なさや, 調理能力の低さで示され るように, 食品の調理方法を十分知らないことも, 男性において使用食品が多様でなかった理由として考えら れる。

男性は，和え物・浸し物・酢の物およびサラダのような副菜の料理の出現率が低かった。針谷(6) 生の自炊食事において, 調理経験が少ない者ほど副菜料理が少ないことを報告している。本調査において男性 
は, 調理能力が低く, 調理経験も女性より少な いと考えてよい。したがって，副菜を組み入れ ることは, 食事作りの経験もしくは調理能力が 主菜より必要とされるものと思われる。

\section{(6) 調味料}

調味料などを, 塩味料・甘味料・酸味料・だ し類などのようにさまざまの料理に使用できる 基本調味料, 香辛料, 料理が指定されている合 わせ調味料,および油脂類 - 粉類などの副材料 に分け，それらの所有数を表 7 に示した。基本 調味料, 合わせ調味料および副材料は女性のほ うが有意に多くの種類を所有していた。香辛料 は, 男女ともその所有数が 1 種類から 6 種類以 上の対象者がいるという偏差の大きさから, 男 女差が認められなかった。個々の食品について みると, 女性のほうが有意に所有者数の多かっ た調味料は, ドレッシング（男性 2 人, 女性 8 人）および食酢（男性 5 人，女性 13 人）であ った。これらは, 男性に作られることの少ない サラダおよび酢の物に使用される物である。ま た, 副材料の所有数には男女差があったが, 油 脂類の所有者数には男女差が認められなかった。 これは，油を用いた焼き物および炒め物の出現 率の男女差が小さいことに呼応する結果と考え られる。以上の結果は, 適用できる調理方法が 所有する調味料に影響されることを示唆してい る。

\section{（7）調理機器および台所}

所有している調理機器の種類数を表 8 に示した。調理機器類の総所有数は, 女性のほうが男性より多かった。 この結果は, 青年の単身者は自炊が多い人ほど調理道具の所有が多いという調査結果 $\left.{ }^{9}\right)$ と致している。中で も, 女性が男性より有意に多く所有している器具は, 下ごしらえ器具, 混合・変形器具, 計量器具および保存 器具であった。熱源機器および加熱器具に男女差はなかったが, これらの調理機器は, 加熱調理に必須なもの として自炊を始める時に揃えられやすいからと推測される。

嗜好飲料器具は, 男性が女性より多く所有していた。全ての調査項目の中で, 男性が女性より有意に高值を 示したものは, この嗜好飲料器具の所有数だけであった。この結果は, 男性は食事そのものよりも, 嗜好飲料 によって下宿における食生活に満足感を得ようとする意識が強いことを示唆している。

台所（調理場所）の状況は，専有できる独立した台所（ダイニングキッチンを含む）のある住居に住む者は

\begin{tabular}{|c|c|c|}
\hline & 男 性 & 女 性 \\
\hline 基 本 調 味 料 & $11.46 \pm 0.50$ & $14.15 \pm 0.52^{* * *}$ \\
\hline 香 辛 料 & $3.54 \pm 0.64$ & $4.62 \pm 0.86$ \\
\hline 副 材 料 & $3.31 \pm 0.35$ & $5.69 \pm 0.52^{* * *}$ \\
\hline 合わせ調味料 & $1.62 \pm 0.33$ & $3.15 \pm 0.50^{*}$ \\
\hline 計 & $19.92 \pm 1.33$ & $27.62 \pm 1.33^{* * *}$ \\
\hline
\end{tabular}

注). $* 1$ 種類数を平均士標準誤差で表した。 男女差 : *** $p<0.001,{ }^{*} p<0.05$

表 8 調理機器の所有数*4

\begin{tabular}{|c|c|c|}
\hline & 男 性 & 女 性 \\
\hline 熱 源 機 器*1 & $4.08 \pm 0.18$ & $3.92 \pm 0.14$ \\
\hline 加 熱 器 具*2 & $4.31 \pm 0.21$ & $4.54 \pm 0.33$ \\
\hline 下ごしらえ器具 & $3.23 \pm 0.20$ & $4.23 \pm 0.34^{*}$ \\
\hline 計 量 器 具 & $0.46 \pm 0.22$ & $1.62 \pm 0.29 * *$ \\
\hline 保 存 器 具 & $0.62 \pm 0.18$ & $1.38 \pm 0.14^{* *}$ \\
\hline 嗜好飲 料 器具 & $1.77 \pm 0.28$ & $0.62 \pm 0.24^{* *}$ \\
\hline 混合·変形器具*3 & $6.08 \pm 0.43$ & $8.54 \pm 0.43^{* * *}$ \\
\hline 計 & $20.54 \pm 0.55$ & $24.85 \pm 1.11^{* * *}$ \\
\hline
\end{tabular}

注）*1 冷蔵庫を含む。

*2一般的ななべ・フライパンは, 大きさの異 なるものを複数もっていても 1 種類として 数えた。

*3 上記分類に含まれない器具を全て含む。し たがって，しゃもじ・玉じゃくし・ざるな どを含み，ボールは大きさの異なるものを 複数もっていても 1 種類として数えた。

*4 数値は, 種類数を平均士標準誤差として表 した。 男女差: ${ }^{* *} \quad p<0.001,{ }^{* *} p<0.01$,
${ }^{*} p<0.05$ 
図 2 主成分分析による因子負荷量

“食品の組み合わせ”悢品組み合わせ良好な食事の出現率，“和之物等”は和之物・浸 し物・酢の物の出現率を表す。他の変数の詳細については, “結果および考察”参照。 次元の固有値：第 1 因子 15.43 , 第 2 因子 7.03

累積寄与率：第 1 因子 $30.9 \%$, 第 2 因子 $44.9 \%$

男性 8 人，女性 2 人に対し，共同の調理場所を使用している者は男性 4 人，女性 10 人であった。女性の中には， 聞き取り調査において共同の調理場所の不便さを訴えた対象者はいたが，同じ下宿に住む学生との共同調理な どの利便性を述べた対象者はいなかった。また，部屋の隅に流しなどのついた簡易調理場所を使用しているの は男女とも 1 人ずっであったが，彼らはそれぞれの性別の中でも自炊回数の多い対象者であった。

\section{2. 各調査結果の関連性}

各調査項目の相互関連をみるために, 自炊・外食・食回数, 調理区分ごとの 1 食当たりの副食料理数, 調 理方法別の 1 食当たり料理出現率, 8 種の食品の展開料理数, 調理能力, 1 食当たりの平均食品数, 食品群ご との使用食品種類数, 食品組み合わせ “良好” な食事の出現率, 調味料などの所有数および調理器具の所有数

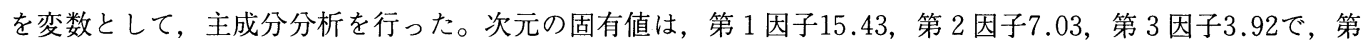
4 因子以降 3 末満であった。対象者数が少なく，変数が多かったので，第 2 因子までを意味のある因子とみな して，因子負荷量を図 2 に示した。

第 1 因子は，自炊回数の負荷量が正に大きく，次食および外食回数の負荷量が負に大きいことから，自炊に 関する因子とみることができる。また第 2 因子は, 食品群別の食品種類数が全て負の負荷量を示し, 汁物およ 
び和え物・浸し物・酢の物の出現率, ならびに玉ねぎ, 卵およびキャベッを用いた料理数が正の大きな負荷量 を示したことから，食材と料理に関する因子と読みとることができる。

第 1 因子の負荷量の大きさから, 自炊回数の多いことは, 調理能力, 自分で作った料理数, 汁物の出現率, 1 食当たりの食品数, 副食の料理に使用される食品の多様性, ならびに混合・变形器具および基本調味料の所 有数と関連が深いことが示された。さらに，自炊回数の第 2 因子負荷量は正值を示すことから，自炊は食材の 種類の多さよりも料理の種類の多さに関連が深いことが示唆された。

第 1 および第 2 因子を合わせて自炊回数に最も近い負荷量をもった変数は, 自分で作った料理数, 調理能力, 1 食当たりの食品数, および汁物の出現率であった。すなわち, 調理能力が高く, 料理を自分で作れることが 自炊するための重要な要素と考えられる。また, 調理の仕方については, 多種類の食品を使い, 汁物を献立に 組み入れることができる者が自炊を続けられることを示唆している。

食品組み合わせ良好な食事の出現率に関する第 1 因子負荷量は, 自炊回数ほど大きくなく, 食品組み合わせ の良好さと自炊回数とはやや離れた関係にあった。すなわち，食品組み合わせの良好な食事の出現率は，自炊 の多いほど多くなる傾向にあるが，この両者の関係は 1 食当たりの食品数または調理能力と自炊回数との関係 より弱いものであった。

次に, 第 1 因子の負荷量が小さい変数から, 自炊の少ない学生の調理の仕方を推定すると, 非調理の料理や 油を用いた炒め物・揚げ物に頼りがちなことがあげられる。また，自炊の多い対象者はにんじんを用いた料理 との，自炊の少ない対象者はキャベッを用いた料理との関係が強いとみることができる。にんじんは加熱調理 の必要性が高い食品であるのに対し，キャベッは炒め物などの短時間の加熱で調理できるだけでなく，生食も できることから，自炊の少ない対象者に使われやすい食品と思われる。さらに，主食に必要な穀類の種類数お よび下ごしらえ器具所有数の因子負荷量が小さいことから，これらの食品および器具が食事作りのうえで最低 限必要と考えられていることを示唆している。

調理機器の所有数は，その分類ごとに分散した位置にあってそれぞれの特徵を示した。まず，混合・变形器 具の所有数は自炊回数と近い関係にあった。混合・変形器具には，すりばちや泡立てのように，適用される調 理操作から見て他の器具で代替の困難な器具が含まれている。したがって，自炊回数と混合・変形器具との関 係の近さは, 自炊回数が多いほど調理操作が多様になることを示唆している。また, 嗜好飲料器具は欠食・外 食の多い対象者に多く所有されるとみられるが，この結果は，自炊の少ない学生にとって嗜好飲料が食生活を 満足させる重要な手段となっていることを示唆している。さらに, 熱源機器は全ての变数から最も離れた位置 にあるが, これは熱源機器が設備的要素が強いため, 食事状況や自炊の仕方に関わりが弱いことを示している。

\section{要 約}

下宿している大学生男女各13人の 3 週間の食生活について, 自炊の仕方を中心に調査し, 以下の結果を得た。

1）男性は女性より自炊回数が少なく，欠食・外食回数が多かった。この食事方法の男女差は，主として朝 食における差によるもので，欠食はそのほとんどが朝食に現れた。また， $2 / 3$ 以上の食事が自炊される時は， 欠食がほとんど現れなかった。したがって，欠食の解消には自炊が必要なことが示された。

2）自炊を多く行うには，調理能力が高く，多種類の食品を用いて料理を自分で作れることが必要であると 示唆された。

3）自炊回数は，1 食当たりの食品数との相関が強かったが，食品組み合わせが良好になることとの関係は 
やや弱かった。

4）自炊回数の少ない対象者は, 非調理の料理または炒め物のような調理の簡便な料理に頼りがちであった。

5）基本調味料および混合・変形器具の所有数は自炊回数との関係が強いことから，自炊の頻度が調味料や 器具の所有に影響することが示された。

6）自炊が少なく，次食・外食が多い場合には，嗜好飲料器具の所有数が多かった。この結果は，自炊の少 ない下宿学生は嗜好飲料で満足を得ようとする意向が強いことを示唆するものである。

本報告は, 筆者の指導のもとに後藤希代美および林加代子が卒業研究として調査を行い, その結果を筆者が まとめたものである。

文 献

1）厚生省保健医療局健康増進栄養課編：国民栄養の現状 昭和58年調査成績（1985）第一出版

2）渡辺悌吉：食の科学, No. 99, 47 53 (1985)

3) 商品科学研究所編：CORE, 7 ( 1 ) (1984)

4）全国大学生活協同組合連合会：第 1 回大学生の食生活報告「大学生の食生活」（1985）

5）全国大学生活協同組合連合会編：大学生の 1 日の食生活 食生活面接調査 205人の実例（1985）

6）針谷順子：家庭科教育学会誌，29, 51～57（1986）

7）太田昌子，田中勢子：家庭科教育学会誌，27，32～38（1984）

8）馬路泰蔵：栄養学雑誌, 39, 259～266（1981）

9）商品科学研究所編：CORE, 11（1）(1984）

10）足立已幸, 針谷順子：食の科学, No. 50, 105 114（1980）

11）山崎清子, 島田キミエ：調理と理論, pp.7２9（1975）同文書院

（受付：昭和62年10月 22 日） 